Original Russian Text (C) 2020 A.S. Plotnikova, A.O. Kharitonova published in Forest Science Issues Vol. 3, No. 4, pp. 1-10

DOI $10.31509 / 2658-607 x-202141 \mathrm{a} 8$

\title{
WEB-BASED GIS FOR MAPPING FIRE REGIMES OF PECHORO-ILYCH RESERVE AND ITS ENVIRONS
}

\author{
A.S. Plotnikova*, A.O. Kharitonova \\ Center for Forest Ecology and Productivity of the RAS, \\ Profsoyuznaya st. 84/32 bldg. 14, Moscow 117997, Russian Federation \\ *E-mail: plotnikova-as-cepl@yandex.ru
}

Received 04.09.2020

Accepted 17.11.2020

The article is devoted to the description of the web-GIS for mapping fire regimes in the Pechora-Ilych reserve and its environs. The main purpose of the resource is to provide the results of mapping fire regimes in the designated area to a wide range of researchers in an accessible form. Web-GIS allows organizing and storing the received thematic spatial data. The resource performs research and educational functions. The structure of the web-GIS includes the following sections: the study area, fire frequency indicators, fire regimes, fire regime condition class, and fire cycles. The web GIS was created using the ArcGIS StoryMaps tool on the ArcGIS Online platform. All sections use data from the ArcGIS Living Atlas of the World. Web-GIS allows receiving reference information about the indicators of fire frequency, fire cycles and regimes, as well as their deviations within the boundaries of the Pechora-Ilych nature reserve, district forestries, and spatial units. In particular, the results of a retrospective statistical analysis of forest fire indicators within spatial units (fire frequency, mean fire interval, etc.) are available for users. StoryMaps.

Key words: web-GIS, fire regime, Pechora-Ilych nature reserve, ArcGIS Online, ArcGIS

At the Center for Forest Ecology and Productivity (CEPF RAS), studies of fire regimes (Barrett et al., 2010) of Russian forests are conducted at all levels - from the national (Plotnikova et al., 2019) to the local (Kharitonova et al., 2019). Local projects include RFBR project No. 17-05-00300 "Development of a methodology for dynamic mapping of fire regimes of forest ecosystems at the local level" (hereinafter referred to as the Project). The Pechora-Ilych Biosphere Reserve and its environs - Kuryinskoye and Yakshinskoye forestry subunits - were chosen as the study area. In the framework of the Project, we developed a method for mapping historical and current fire regimes at the local level. To describe the study area, we generated a number of thematic maps of terrestrial ecosystems based on Landsat satellite data, fire cycles, historical and current fire regimes.

The purpose of this study was to create a web-GIS for providing the results of mapping the fire regimes of the Pechora-Ilych Reserve and its environs to a wide range of researchers in an accessible form. We solved the following tasks: studying the functionality of web-GIS; creating the structure of the system, choosing the optimal composition and content of its sections, determining the means for displaying spatial data; selecting a technological platform for implementing the web-GIS structure.

In the framework of our research, we studied the functionality of web-GIS. This is a distributed geoinformation system that 
consists of two parts - a GIS server and a client (web browser, desktop or mobile application) (Katsko, 2006). Web technology is used to establish communication between the server and the client. Web-GIS has many important features and functions: global coverage and ensuring simultaneous work of many users located anywhere in the world; cross-platform compatibility and a single update mechanism, no fees and no need to purchase specialized software; provision of easy access to the resource for non-specialists; publicly available spatial basis; data scaling option (Shokin, Potapov, 2015; Alekseenko et al., 2019).

A detailed analysis of Russian scientific and educational geoportals of protected areas is given in the article (Alekseenko et al., 2019). Authors divided interstate, national, and regional network resources with data on protected areas into three groups: inventory, multipurpose, and own geoportals. Also they considered the cases of using web-GIS in the following reserves: the Taimyrsky, the Dagestansky, the Stolby, and the Belogorye. The analysis showed that most of the Russian web-GISs use open-source software. The commercial platforms use Esri and GeoMixer products. In terms of functionality, only visualization of spatial data is usually implemented. There is a lack of digital and cartographic information.

The provision of free or differentiated access to the reserve's web-GIS is determined by the goals of its creation. Publicly accessible geoportals (i.e., the Dagestan and Pechora-Ilych reserves) are developed for tourists, students of specialized universities, employees of scientific organizations, and specialists in the field of environmental protection. Access can be restricted, in particular, when developing a system for combining the scientific work of employees of different profiles of one reserve on an Internet platform (Alekseenko, Samoletova, 2017). An example of differentiated access is the web-GIS of the Belogorye reserve (http://belogorie.maps.arcgis.com/home/index .html).

The indicated lack of digital data is noted in the Pechora-Ilych Reserve's web-GIS, which was created by the NextGIS company (http://pechora-reserve.nextgis.com/resource/108 /display?panel=layers). It presents a set of layers: border of the protected areas (border of the reserve and the buffer zone), zoning of the protected areas (forest districs of the reserve), infrastructure, topography (isohypses, swamps, hydrography), ecological routes and attractions (ecological routes, weathering pillars of ManPupunyor, photographs). Thus, at present, webGIS lacks thematic spatial data. The user has access to the functions of scaling, measuring distance, and area on the map, and the vertical shutter tool. The OpenStreetMap resource is used as a cartographic basis (https://www.openstreetmap.org).

Among the publicly available web-GIS reserves, we note the developments of the Data East company. The company has created interactive maps to provide travelers with the necessary information about recreation sites, transport infrastructure, hydrography, tourist routes, and natural attractions (https://carrymap.com/ru/gallery/maps-foroutdoor-activity/). In Russia, digital maps were generated for reserves such as the Russian Arctic National Park in the Arkhangelsk Region, the Kuril Nature Reserve in the Sakhalin Region, the Kandalaksha Nature Reserve in the Murmansk Region, and others. In the USA, maps were generated for the Glacier, Sequoia, and Zion National Parks. Resources are accessed via the free CarryMap app (https://carrymap.com/en/support/ carrymapfor-windows/), which allows using them without an internet connection.

For example, the map of the Kuril Nature Reserve includes the marks of the main attractions and infrastructure (parking lots for tourists, ports, shops, pharmacies, hospitals, and post offices) and descriptions of natural objects (capes, bays, mountain peaks, and notches) (https://carrymap.com/ru/gallery/mapgallerylibrar y/maps-for-outdoor-activities/kurils-naturereserve-kunashir-island/). To create the base map, we used an up-to-date topographic map at a scale of $1: 100,000$.

Analysis of the web-GIS's functions and examples of their implementation showed that it is feasible to use this technology to achieve the goal set in the study.

\section{MATERIAL AND METHODS}

As noted above, the choice of the type of web-GIS is largely determined by the goals of 
its creation. Web-GIS of fire regimes should perform research and educational functions. It is also designed to solve problems such as notification of the scientific community about new results in the study area, systematization and storage of the received thematic spatial data, and viewing materials by non-GIS specialists.

When creating a web-GIS structure, the main criteria were the simplicity and clarity of the resource for the user as well as the provision of him/her with the necessary information content. The composition and content of the system's sections should be sufficient to determine the fire regimes in the study area, spatial study of the most important fire indicators, and natural conditions. In addition, the system should provide the ability to assess the deviations of fire regimes from their historical values. Deviations lead to the transformation of key components of ecosystems and changes in the frequency and severity of fires. It requires a section that would contain one of the important characteristics of the fire regime - the fire cycle, which estimates the time required to burn out forest area equal to the area of the spatial unit of damage analysis (Frech et al., 1999). Thus, the web-GIS includes the following sections: study area, fire indicators, fire regimes, fire regime condition class, fire cycles (Fig. 1).

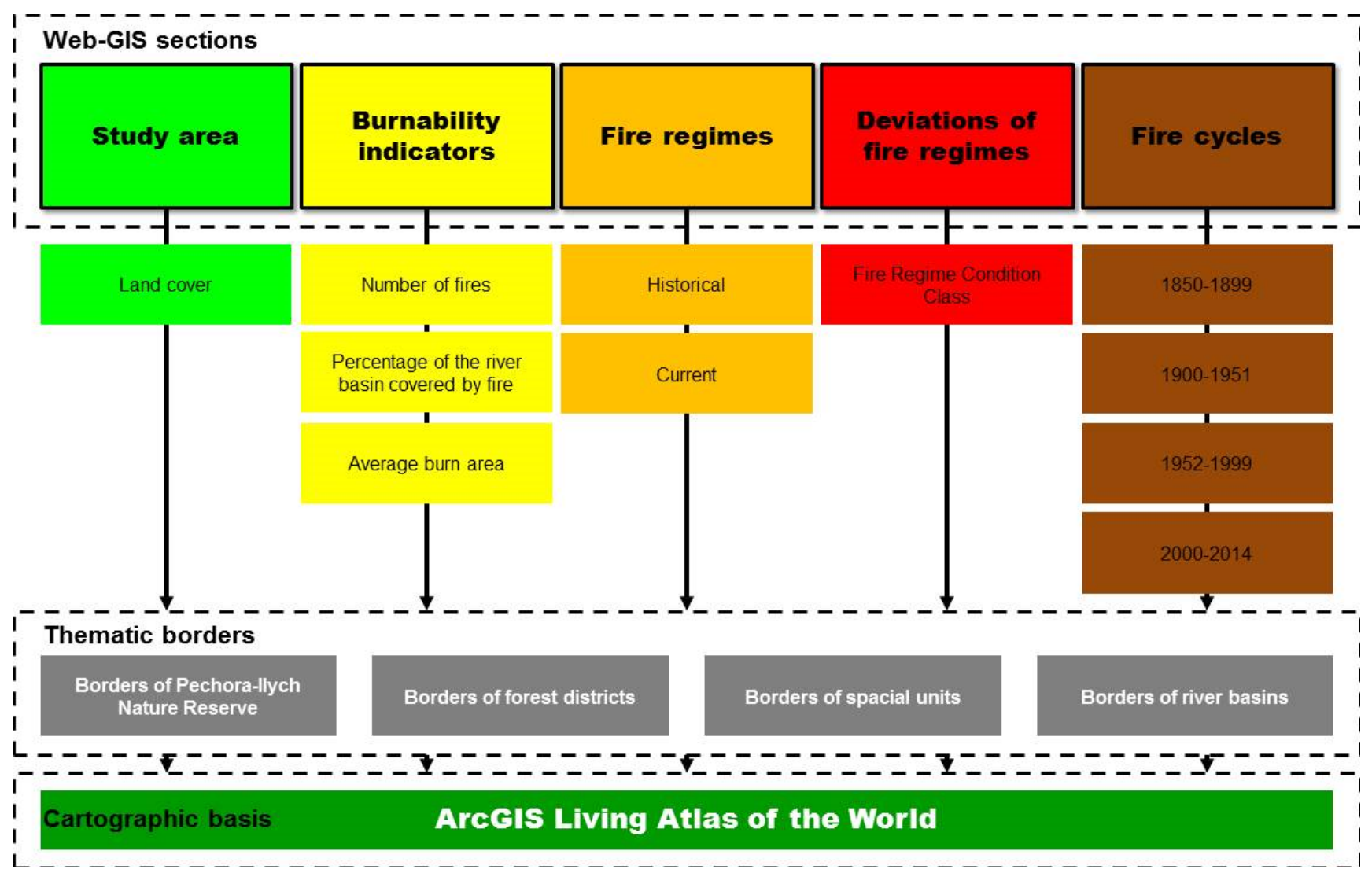

Figure 1. The web-GIS structure of fire regimes of the Pechora-Ilych nature reserve and its environs

The Study Area section contains data obtained in the study of the physical and geographical conditions and vegetation cover of the region under study (Gavrilyuk et al., 2018). The section contains cartographic layers with the boundaries: Pechora-Ilych nature reserve, Kurinsky and Yakshinsky district forestries, river basins, and spatial units. The interactive use of the map suggests the use of a "pop-up window", which allows obtaining numerical and graphical information about the ratio of vegetation cover classes in the total area of a spatial unit.

The Fire Indicators section presents statistical data on the number and average area of fires, the share of the area covered by fire within the boundaries of spatial units. The "pop-up window" also provides information on the fire indicators within the boundaries of the reserve and forestry areas, indicating the 
data source (aviation, historical). The results of mapping historical and current fire regimes are reflected in the Fire Regimes section. Interactive work with the map allows receiving information about the type of fire regime for each spatial unit. For the reserve and forestry, information is provided on the ratio of areas of different classes of fire regimes. The section Fire Regime Condition Class is included in the web-GIS to represent the classes of the state of the fire regime. The Fire Cycles section contains maps of fire cycles for the main part of the Pechora-Ilych Reserve for four time periods: 1850-1899, 1900-1951, 1952-1999, and 2000-2014. Additional indicators used in calculating cycles include area covered by fire, forest area, and study period.

According to the work of N.A. Alekseenko (2014) when creating a geoportal for any reserve, it is advisable to use a map of natural boundaries to combine various information. Thus, all the sections of the web-GIS of fire regimes contain a map of spatial units based on the boundaries of river basins (Plotnikova, Kharitonova, 2018). Mapping of fire regimes and cycles was conducted within the boundaries of spatial units; we collected statistical information on groups of tree species, class of fire regime, and fire indicators.

When choosing a technological platform for implementing the structure of web-GIS fire regimes we took into account the need to develop a simple, intuitive, and convenient interface. This requirement is preconditioned by the wide target audience of the system, which do not necessarily have the skills to work with spatial data in professional geographic information systems. During the study, we considered modern technological platforms such as GeoMixer, MapBox, Mangomap, Azimap, and ArcGIS Online. In addition to ease of use and free access, the possibility of publishing spatial data on a basic interactive map was taken into account.

GeoMixer is a web-based geoinformation platform used to solve a wide range of tasks for visualization, analysis, organization, and data integration (http://geomixer.ru). To create a web-GIS on the GeoMixer platform, it is necessary to pre-install a number of software components - Microsoft IIS web server, Microsoft.NET Framework, PostgreSQL DBMS, or MS SQL Server. In addition, there are requirements for minimum recommended hardware configuration including restrictions on bit capacity of a multi-core processor, size of the RAM and redundant array of independent disks (RAID). Unlike GeoMixer, MapBox (https://www.mapbox.com), Mangomap (https://mangomap.com), and Azimap (https://www.azimap.com) platforms allow generating interactive web maps without installing additional software. The platforms include the functions of visualization and analysis of spatial data, generation and thematic design of web maps. Open Street Map data is used as a cartographic basis.

ESRI's ArcGIS Online platform is one of the world leaders in geographic information systems (https://www.esri-cis.ru/). It allows creating, storing, and managing web maps, applications, and other spatial data. The platform was chosen to create a web-GIS of fire regimes because it allows for free creation of a cartographic resource for the research project. In addition, ArcGIS Online allows using data and maps from the ArcGIS Living Atlas of the World. It is the most complete collection of global geographic information available today (base maps, satellite images, statistical information, etc.).

RESULTS AND DISCUSSION
Our web-GIS of fire regimes
(http://cepl.rssi.ru/fire-regime-pechora-reserve/)
allows visualizing and analyzing the spatial
data created within the framework of the
Project without the use of specialized
professional full-featured geographic
information systems. Thus, the resource
provides the obtained cartographic results in a
form accessible to a wide range of researchers
(Fig. 2).
(Fig. 2). 


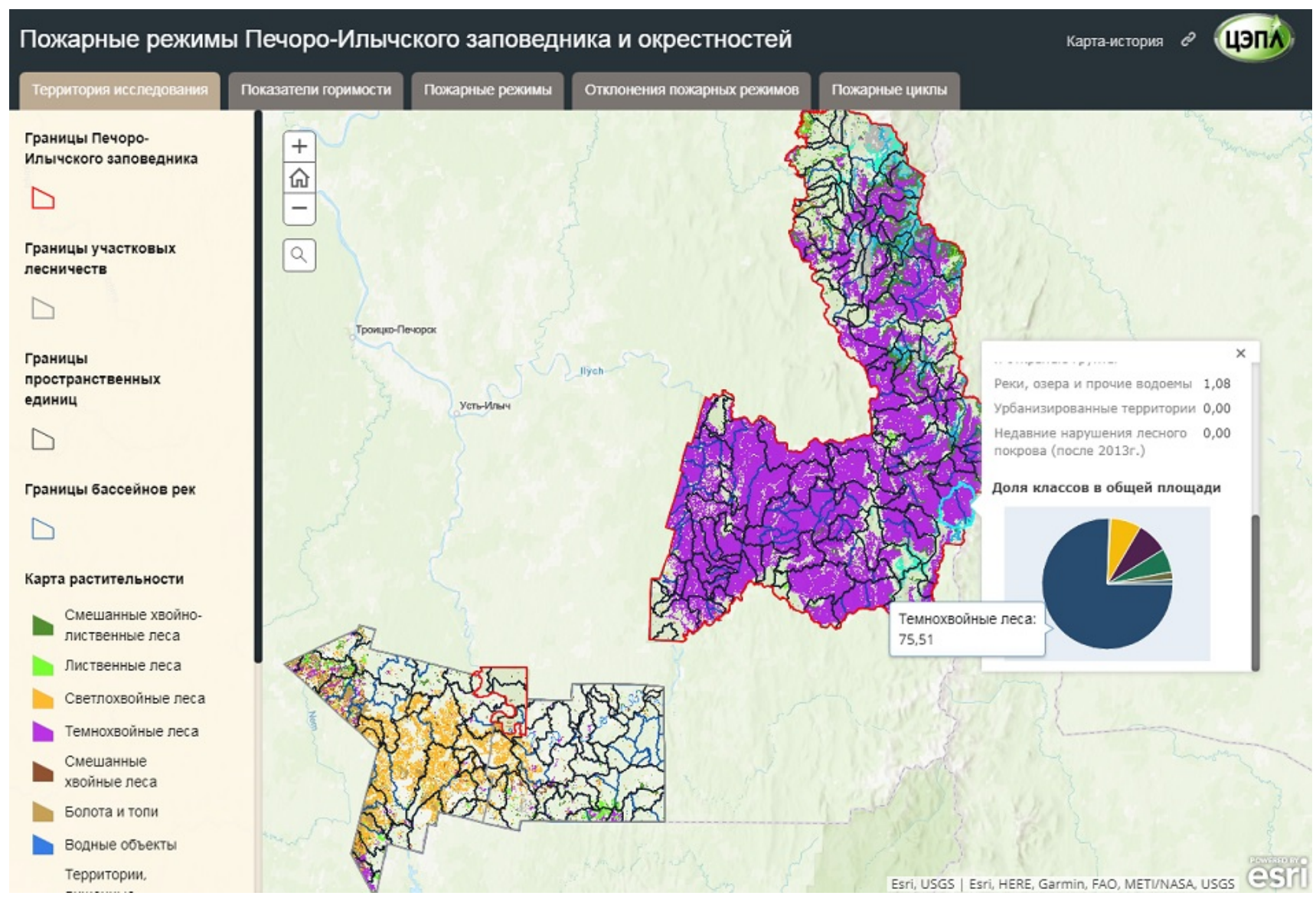

Figure 2. The Web-GIS interface of the study area fire regimes

Using the ArcGIS StoryMaps tool on the ArcGIS Online platform, we generated interactive thematic maps showing study area, fire indicators, fire regimes, fire regime condition class, and fire cycles (Fig. 3). The ArcGIS Living Atlas of the World (https://livingatlas.arcgis.com/en/home/) was used as a cartographic basis for visualizing the spatial data of the Project. It is a collection of shape maps, geodata layers, images, and applications. In addition, the Living Atlas provides a regularly updated public basemap of high and ultrahigh resolution space images for the territory of Russia. We have chosen a base containing hydrographic objects, settlements, relief, and administrative boundaries of the constituent entities of the Russian Federation for all interactive maps.

Web-GIS allows to obtain the reference (attributive) information about fire indicators, fire cycles, and regimes, as well as fire regime condition class within the boundaries of the Pechora-Ilych nature reserve, district forestries, and spatial units. In particular, we dispose of the results of a retrospective statistical analysis of fire indicators within spatial units (fire frequency, mean fire interval, and others).

Research in the territory of the PechoraIlych Reserve is conducted in various scientific areas (Smirnova et al., 2011; Shevchenko, 2015; Geraskina, 2016; etc. However, it is difficult to find works that graphically represent the obtained spatial results with the possibility of interactive access. Thanks to this study, the results of mapping the fire regimes of the reserve and its environs became available to a wide range of specialists. 


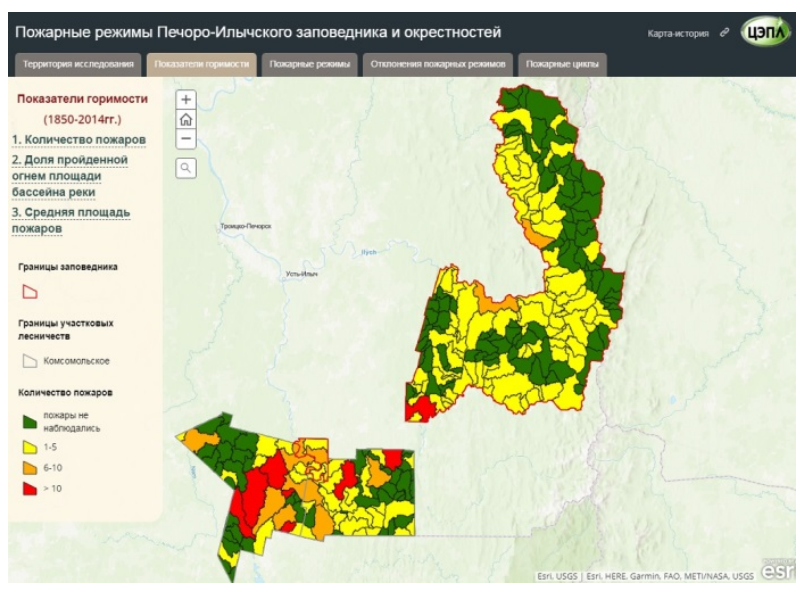

a)

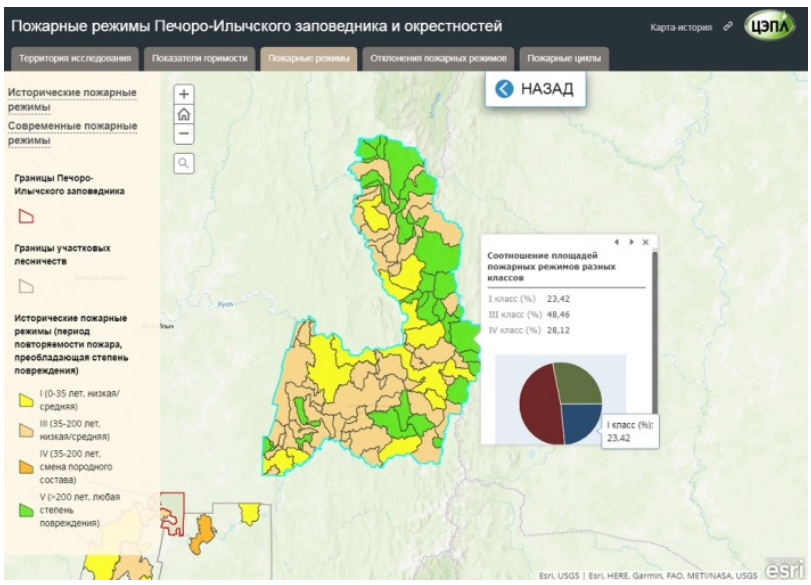

c)

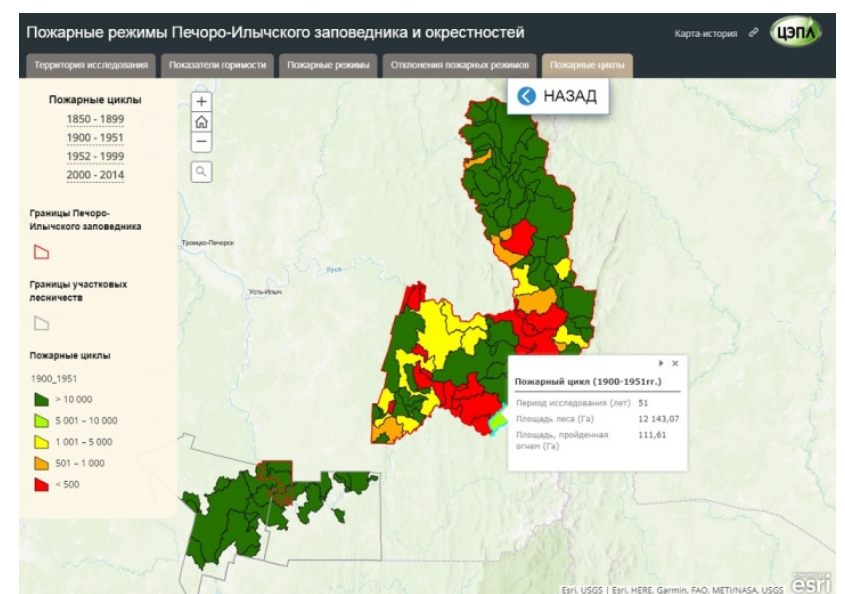

b)

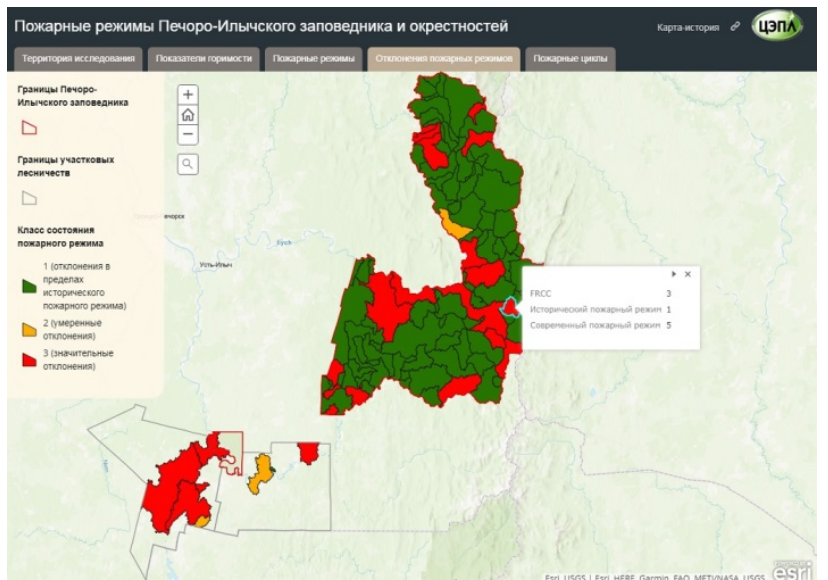

d)

Figure 3. The web-GIS sections: a) burnability indicators, b) fire cycles, c) fire regimes, d) fire regime condition class

\section{CONCLUSION}

The study resulted in designing a web-GIS of fire regimes in the Pechora-Ilych reserve and its environs. Thanks to our resource, various characteristics of the fire regimes of the study area are available to a wide range of researchers involved in geoecology, forest management, climatology, pyrology, and related scientific fields.

We indicated the functions performed by the web-GIS and the tasks to be solved. We determined the structure of the web-GIS and developed the composition and content of the system sections. We substantiated the choice

\section{REFERENCES}

Agee J.K., Fire ecology of Pacific Northwest forests, Island Press: Washington, DC, 1993, p. 493.

Alekseenko N.A., Edinaja baza dannyh OOPT Rossii (Unified database of protected areas of Russia), Proc. 15th of a technological platform for the implementation of a geographic information system in the Internet.

\section{ACKNOWLEDGEMENTS}

The study was conducted with the financial support of the Russian Foundation for Basic Research (project No. 17-05-00300) and within the framework of the state assignment AAAA-A18-118052400130-7

"Methodological approaches to assessing the structural organization and functioning of forest ecosystems".

International Scientific Conference "Conservation of Biodiversity of Kamchatka and Coastal Waters", Petropavlovsk-Kamchatsky, 17-18 November 2014, PetropavlovskKamchatsky: Kamchatpress, pp. 113-117. 
Alekseenko N.A., Koshkarev A.V., Kuramagomedov B.M., Medvedev A.A., Geoportaly rossijskih osobo ohranjaemyh prirodnyh territorij (Geoportals of Russian Specially Protected Natural Areas), Geodezija i kartografija, 2019, Vol. 80, no.5, pp. 34-46.

Alekseenko N.A., Samoletova M.I., Predlozhenija po sozdaniju geoportala dlja obespechenija nauchnoj raboty zapovednika "Belogor'e" (Proposals for the creation of a geoportal to support the scientific work of the "Belogorye" reserve), Proc. 7th International Scientific Conference "Problems in Nature Management and the Ecological Situation of European Russia and Adjacent Countries" (in Memory of Prof. A. Petin), Belgorod, 24-26 October 2017, Belgorod: Politerra, pp. 379-384.

Barrett S.W., Havlina D., Jones J., Hann W., Frame C., Hamilton D., Schon K., Demeo T., Hutter L., Menakis J., Interagency Fire Regime Condition Class Guidebook. Version 3.0., 2010, available at: https://www.landfire.gov/frcc/frcc guideb ooks.php (August 12, 2020).

Frech R.J., Caputo J.A., McCulloch K., Forest fire cycle analysis for applications in forest management planning. Ontario Ministry of Natural Resources AFFM Publication. 1999. No. 362.1999.

Gavriljuk E.A., Plotnikova A.S., Plotnikov D.E. Kartografirovanie nazemnyh jekosistem Pechoro-Ilychskogo zapovednika i ego okrestnostej na osnove vosstanovlennyh mul'tivremennyh sputnikovyh dannyh multirial-Landsat based the reconciliation of the dannyh Landsat satellite data), Sovremennye problemy distancionnogo zondirovanija Zemli iz kosmosa, 2018, Vol. 15, No.5, pp. 141-153.

Geraskina A.P. The population of earthworms (Lumbricidae) in the main types of dark coniferous forests in Pechora-Ilych Nature Reserve, Biology Bulletin, 2016, Vol. 43, No. 8, pp. 819-830.

Haritonova A.O., Plotnikova A.S., Ershov D.V., Sovremennye i istoricheskie pozharnye rezhimy Pechoro-Ilychskogo zapovednika i ego okrestnostej (Current and historical fire regimes of Pechora-Ilych nature reserve and its surroundings), Voprosy lesnoj nauki, Vol. 2, No. 3, pp. 117.

Kacko S. Ju., Klassifikacija i principy raboty geoinformacionnyh WEB-serverov $\mathrm{v}$ internet-sisteme "Klient-Server" (Classification and principles of operation of geoinformation WEB-servers in the Internet system "Client-Server"), GeoSibir, 2006, Vol. 1, No.1, pp. 211-215.

Plotnikova A.S., Ershov D.V., Haritonova A.O., Shuljak P.P., Bartalev S.A., Stycenko F.V., Prostranstvennaja ocenka sovremennyh pozharnyh rezhimov lesnyh jekosistem Rossii (Spatial assessment of modern fire regimes of forest ecosystems in Russia), Sovremenyye problemy distancinnogo zondirovaniya Zemli iz kosmosa, 2019, Vol. 16, No. 5, pp. 228240

Plotnikova A.S., Haritonova A.O., Vydelenie granic vodosbornyh bassejnov rek na lokal'nom prostranstvennom urovne (The identification of drainage basins borders at local spatial level), Voprosy lesnoj nauki, 2018, Vol. 1, No.1, pp. 1-10.

Shevchenko N.E., Soobshchestva sosnovoelovykh lesov verkhnei chasti basseina $r$. Pechory (Pechoro-Ilychskii biosfernyi zapovednik, Sobinskii uchastok) (Communities of pine-spruce forests in the biopart of the Pechora site-Ilybinsky river basin (Pechora-Ilychsky Biosphere Reserve, Sobinsky site)), Lesotekhnicheskii zhurnal, 2015, Vol. 5, No. 3 (19), pp. 142152.

Smirnova O.V., Aleinikov A.A., Semikolennykh A.A., Bovkunov A.D., Zaprudina M.V., Smirnov N.S., Prostranstvennaya neodnorodnost 'pochvenno-rastitel'nogo pokrova temnohvojnyh lesov v Pechoro-Ilychskom zapovednike (Spatial heterogeneity of the soil-plant cover in dark coniferous forests of the Pechoro-Ilychskii Reserve), Lesovedenie, 2011, No. 6.pp. 67-78.

Shokin Ju.I., Potapov V.P., GIS segodnja: sostojanie, perspektivy, reshenija (GIS today: current state, perspectives, solutions), Vychislitel'nye tehnologii, 2015, Vol. 20, No. 5, pp. 175-213. 
Reviewer: Ph.D. in biology, Director of the Center for Forest Pyrology R.V. Kotelnikov 